\title{
The formation of bachelors' digital competencies at the university
}

\section{Formación de competencias digitales de licenciados en la universidad}

\author{
Julia M. Tsarapkina
}

Russian State Agrarian University - Moscow Timiryazev Agricultural Academy, Moscow, Russia.

ORCID: https://orcid.org/0000-0002-3807-4211

\section{Lyudmila N. Plahina}

Penza State Technological University, Penza, Russia, Russia

ORCID: https://orcid.org/0000-0002-7832-2494

\section{Natalia V. Konoplyuk}

Togliatti State University, Togliatti, Russia

ORCID: https://orcid.org/0000-0001-7865-5144

\section{Olga I. Vaganova}

Minin Nizhny Novgorod State Pedagogical University, Nizhny Novgorod, Russia.

ORCID: https://orcid.org/0000-0001-8347-484X

\section{Anna V. Lapshova}

Minin Nizhny Novgorod State Pedagogical University, Nizhny Novgorod, Russia.

ORCID: https://orcid.org/0000-0001-7017-3589

Received 02-12-20 Revised 04-25-20

\section{*Correspondence}

Email: ivannovadremova29@gmail.com
Accepted 08-13-20 On line 09-29-20

\section{Cite as:}

(c) Universidad San Ignacio de Loyola, Vicerrectorado de Investigación, 2020. 


\section{Summary}

The development of modern information and communication technologies leads to the emergence of new requirements for the preparation of bachelors of higher educational institutions. These requirements justify the need for digital competencies. The process of their formation in the conditions of informatization of vocational education is of high importance. Digital competencies contribute to the creativity of thinking, an initiative in achieving goals, the formation of cognitive skills, including a focus on self-development and achieving high results, increasing the competitiveness of the bachelor in the labor market. The purpose of the article is to analyze the experience of the formation of digital competencies of bachelors by higher educational institutions. These competencies represent the ability and willingness to use electronic educational resources for educational and professional activities. Digital competencies are based on computer literacy and the independence of digital tools. Digital competencies reflect the use of digital teaching aids - a set of methods and technologies used in digital didactics. New electronic tools were introduced into the educational process, which was used by students in carrying out professional activities. Electronic technologies were used as the main and additional educational materials in the organization of individual and group work.

Keywords: bachelors, digital competencies, electronic educational resources, higher education institution, professional education.

\section{Resumen}

El desarrollo de las tecnologías modernas de la información y la comunicación conduce a la aparición de nuevos requisitos para la preparación de licenciados de instituciones de educación superior. Estos requisitos justifican la necesidad de competencias digitales. El proceso de su formación en las condiciones de informatización de la educación profesional es de gran importancia. Las competencias digitales contribuyen a la creatividad del pensamiento, una iniciativa en el logro de metas, la formación de habilidades cognitivas, incluyendo un enfoque en el autodesarrollo y lograr altos resultados, aumentando la competitividad del bachillerato en el mercado laboral. El propósito del artículo es analizar la experiencia de formación de competencias digitales de licenciados por instituciones de educación superior. Estas competencias representan la capacidad y la voluntad de utilizar recursos educativos electrónicos para actividades educativas y profesionales. Las competencias digitales se basan en la alfabetización informática y la independencia de las herramientas digitales. Las competencias digitales reflejan el uso de ayudas didácticas digitales, un conjunto de métodos y tecnologías utilizados en la didáctica digital. Se introdujeron en el proceso educativo nuevas herramientas electrónicas, que fueron utilizadas por los estudiantes en el desarrollo de actividades profesionales. Las tecnologías electrónicas se utilizaron como material educativo principal y adicional en la organización del trabajo individual y grupal.

Palabras clave: licenciaturas, competencias digitales, recursos educativos electrónicos, institución de educación superior, educación profesional.

\section{Introducción}

The increasing digitalization of society affects all spheres of human life. The education sector, being one of the most dynamic environments, is one of the first to absorb innovative resources (Andriushchenko, 2018). The development of modern information and communication technologies causes the emergence of new requirements for the preparation of bachelors of higher education institutions (Aleksieienko-Lemovska, 2019). Legal documents regulating the digital educational process, including the Federal state educational standards of higher education (Oros, 2018), establish the need for the formation of digital competencies of students (Andrienko, 2019a). These competencies include thr confident use of electronic resources for the implementation of educational and future professional activities (Andrienko, 2019b). The concept of competence is 
considered as a set of knowledge, skills and experience for the successful solution of professional tasks (Donetskova, 2019). Digital competencies are based on computer literacy and independent use of electronic tools in the organization of their own activities (Filchenkova, 2019). Digital competencies also reflect the use of digital learning tools, a set of methods and technologies used in digital didactics (Klinkov, 2018).

The formation of digital competencies is carried out within the digital educational environment (Halatsyn \& Feshchuk, 2019). The digital educational environment is a system of conditions and opportunities that includes information and communication infrastructure and a set of digital technologies and resources for learning (Pliushch, 2018).

To develop digital competencies, it is important to understand the overall structure and relationship of electronic devices (Vaskovskaya et al., 2018); to understand the potential of digital technologies in the organization of activities (Pichugina \& Zhilyakova, 2019). The success of professionally-oriented educational activities depends on the level of formation of students ' digital competencies and their ability and readiness to apply them in information-intensive practical activities (Petrichev et al., 2018). Various electronic tools are introduced into the training of students, which are used by them when preparing for classes, performing tasks. In the course of training, students gain experience in developing interactive tests and tasks, design training sessions using various digital educational resources, and use digital technologies at various stages of independent work (Arbeláez-Campillo, \& Rojas-Bahamon, 2020).

The structure of digital competence is represented by three components: motivational; information technology; and communication. In our work, using the introduction of digital technologies in the training of students, we form each of the presented components. To increase the level of formation of digital competencies, electronic technologies were used as basic and additional training materials in the organization of individual and group work (Pinkovetskaia et al 2020). The higher the level of competence formation, the more quickly the student navigates in the modern information environment, uses Federal repositories of information educational resources, electronic libraries (Pisarenko, 2019). The student structures information in electronic information networks accordingly, presents it in the form of graphs and diagrams, captures and processes images, and so on. The formation of digital competencies also includes knowledge of network etiquette, safe behavior on the Internet, and the ability to perform with audio and video support, including for a virtual audience. We identified three levels of digital competence formation (high, medium, and low). The article presents its characteristics.

\section{Theoretical framework}

The formation of competencies is a long and multifaceted process. Features of the formation of significant ones for future professional activity are considered in the works of N. P. Bakhareva (Bakhareva, 2019). The value of digital resources in training students is presented in the works of O. O. Chertovskikh (Chertovskikh, 2019).

According to a number of experts (K. E. Bezukladnikov, A. Yu. Muratov and others), the introduction of innovative technologies has allowed expanding the training of students (Vaganova et al., 2019a), to introduce electronic elements that make the work of students more mobile and operational (Vaganova et al., 2019b). A study of research in the field of bachelor's training in higher education institutions has shown that the relevance of digital competence formation is becoming higher every year (Tolkanuk, 2019). Innovative technologies in the system of continuing education have a positive impact on the professional competence of students of higher educational institutions - notes A. p. Cirdan (Cirdan, 2019). A.V. Ponachugin allocates digital educational resources of the University (Ponachugin \& Lapygin, 2019). Improving the quality of the educational process through the introduction of innovative electronic applications is considered by Yu. a. Tsarapkina (Tsarapkina et al., 2019b). 
A. A. Andreev, S. A. Beshenkov, I. p. Gladilina and others devoted their works to the study of digital technologies in the field of education. The importance of digital competence formation in the conditions of the informatization of education is emphasized by M. p. Lapchik. S. M. Gushchina considers the formation of digital competencies using digital technologies.

Scientists note the significant role of technical equipment of the University's educational space in the formation of digital competencies (Gladkov et al., 2019). The presence of a sufficient amount of electronic equipment makes it possible to organize a productive educational processaccording to C. S. Conway and a.m. Quarles (Quarles et al., 2017). K. Frost emphasizes that activities related to the use of the Internet create a new functional and spatial interaction (Frost et al., 2018). The researchers emphasize that communication and interaction skills are important in the formation of digital competencies (Grigoriev et al., 2019). In the course of training, students must master the skill of network etiquette and rules of communication in the network, use audio and video tools, send emails, files, and send newsletters to the target audience (Raven, 2017).

\section{Methodology}

The study was attended by 96 students of higher education institutions. In 2017, 2018 and 2019, we conducted work to identify the level of formation of digital competencies.

High, medium and low levels of digital competence formation are characterized by separate indicators presented in Table 1.

Table 1.

Characteristics of the levels of students' formation of digital competence.

\begin{tabular}{|c|c|}
\hline Level & Characteristic \\
\hline High & $\begin{array}{l}\text { The student is interested in using digital technologies and electronic educational } \\
\text { resources in educational activities; shows steady interest in the use of electronic tools } \\
\text { to increase the effectiveness of task performance ; demonstrates skills in working } \\
\text { with multimedia equipment and electronic educational resources ; able to process } \\
\text { numerical data using statistics and visualization tools (graphs, charts, tables, mental } \\
\text { maps and others); shows formed search sampling skills of the selection of relevant } \\
\text { information sources ; know and actively using tools and videoconferencing -bond, } \\
\text { webinars and streams ; the mind is to conduct business correspondence through the } \\
\text { use of email, chat and private messages of e-learning platforms; He owns skill s work } \\
\text { with social networks, blogs for educational purposes ; able to widely and variably use } \\
\text { information technology and spend minimal time on the implementation of } \\
\text { information processes }\end{array}$ \\
\hline Middle & $\begin{array}{l}\text { The student is partially interested in using electronic resources; can work with } \\
\text { multimedia equipment ; has difficulty processing numerical data using statistics and } \\
\text { visualization tools; shows the generated skills of a search sample, the selection of } \\
\text { relevant sources of information; knows and uses video conferencing, webinars } \\
\text { and streams; knows how to conduct business correspondence through the use of e- } \\
\text { mail, chats and personal messages of electronic educational platforms; able to work } \\
\text { with social networks, blogs for educational purposes; can use information } \\
\text { technology, but the implementation of information processes is difficult }\end{array}$ \\
\hline Low & $\begin{array}{l}\text { Student shows little interest in the use of digital technology in } \\
\text { educational activities ; uses electronic tools for file transfer; uses electronic } \\
\text { educational resources ; working with multimedia equipment is difficult; prepares the } \\
\text { results of their own activities most often in text format; It has great difficulty in } \\
\text { processing numerical data using statistics and visualization tools; able to search for } \\
\text { information on the Internet; knows and uses video conferencing, webinars } \\
\text { and streams ; knows how to conduct business correspondence through the use of e- } \\
\text { mail, chats and personal messages of electronic educational platforms; able to work }\end{array}$ \\
\hline
\end{tabular}


with social networks, blogs for educational purposes; can use information technology, but it takes a lot of time to implement information processes

The students' study of the block of professional disciplines was accompanied by project work, case tasks, and business games. Students ' activities were carried out using text editors, spreadsheets, databases, and electronic educational platforms. Students also performed interactive tests related to the search, processing and presentation of information (Chil Núñez et al, 2020). The test provides questions that reflect the formation of a specific component of digital competence. The indicator of digital competence formation ranges from $0 \%$ to $100 \%$ the Indicator from $0 \%$ to $45 \%$ reflects a low level of competence formation, from $46 \%$ to $70 \%$ - average, from $71 \%$ to $100 \%$ - high.

\section{Results and discussion}

Digital competencies include the following components: motivational; information technology; and communication.

The motivational component reflects the conscious need to master digital competencies, the need for self-education and professional self-improvement through electronic means, and a deep awareness of the role of information technologies and electronic tools in the activities of a modern bachelor.

The information technology component includes the ability to formalize the results of their own activities in various formats (text, graphic, audio-visual), the ability to use programs for numerical data processing, to search for relevant information on the Internet. This component is characterized by an understanding of global computer networks, includes an understanding of the information picture of the world, knowledge of the basic methods of obtaining, storing and transmitting information, the ability to subject information to structuring, analysis, comparison and generalization.

The communication component represents students' knowledge of ways to organize communication through electronic means for educational purposes, reflects the ability and readiness to organize interaction in local and global networks (Vaganova et al., 2019c).

In the process of studying professional disciplines, students completed projects, solved case tasks, and took part in business games. Students also performed interactive tests related to the search, processing and presentation of information. The test provides questions that reflect the formation of each specific component of digital competence.

E-libraries (e-library, Cyberleninka, and others) offer a wide range of opportunities for preparing for classes and performing independent work. Students develop skills in using databases containing regulatory documentation ("Consultant+", "guarantor"). Databases allow you to develop the skill of working with information on the Internet, quickly select the most relevant material. Students also used the technical capabilities of Moodle, an electronic educational platform. Moodle allows students to organize online interaction both among themselves and with the teacher. Students exchange files, participate in discussions and consultations. Forum, chat, and webinar allow students to learn the basics of networking for educational purposes.

Skype, chat, forum, and email were also used to organize interaction.

Promising directions in the formation of digital competencies are cloud and blockchain technologies (Cloud), technologies of deep immersion in the professional environment (Deep learning). Students were given the opportunity to test these technologies in the digital space of higher education institutions. The first experience of using them has shown that the educational process is becoming more dynamic. These technologies allow you to combine information 
resources and make their use easier and faster. Blockchain technologies allow organizing the active interaction of participants of the educational process, using the cloud information space.

To organize the most effective learning process and the formation of digital competencies, in particular, a survey was conducted among students, which allowed them to identify the electronic tools often used by students. The results are shown in figure 1.

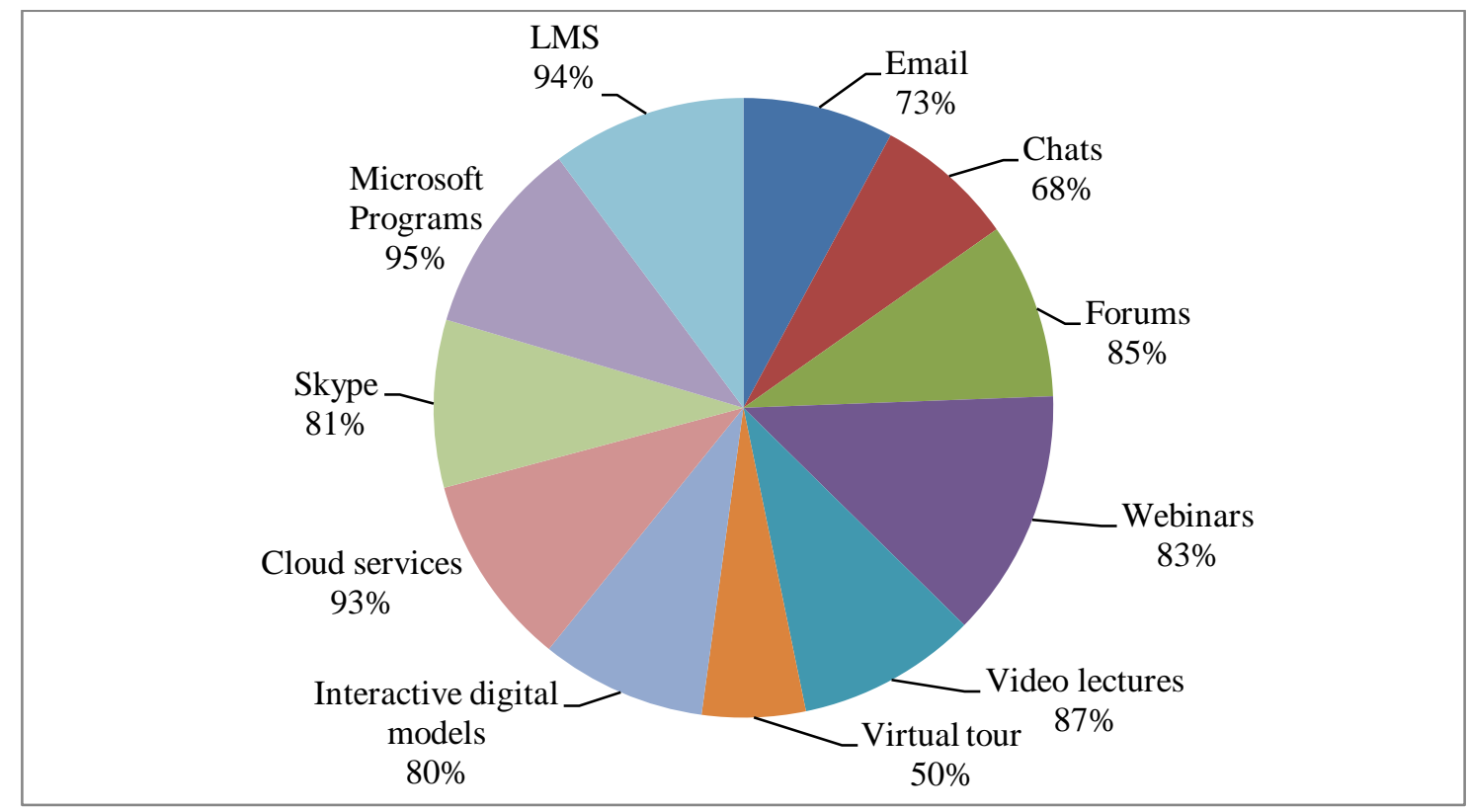

Fig. 1. Results of a survey of students about the use of electronic tools (as part of our study).

Most often, students use Microsoft programs. The main educational tasks are carried out within the framework of Word and Excel. These programs are firmly entrenched in the educational process and do not lose relevance for a long time. A significant percentage of students note the importance of learning management systems or electronic educational platforms (LMS). In the process of preparing students, LMS Moodle is used. Its popularity among students is due to the fact that it includes a large number of electronic tools for completing tasks and organizing interaction. To gain access to an element, a student just needs to go to the site.

Of great interest to students are the recently introduced cloud services - Dropbox, Google Drive, iCloud, Cloud Mail, data warehouses.ru. Their use expands the possibilities of project management and teamwork. Some of them integrate with many Google services: from " Gmail " to " Google Photos", forming students with additional skills in working with digital tools. Students often use video lectures to repeat material. It is worth saying that often teachers post lectures in video format on the Moodle electronic platform. Forums and skype are of particular interest to students. More than $80 \%$ of students use them in their educational activities. Less popular are chat rooms, email, and virtual tours. The opportunity to exchange messages and files is an electronic educational platform. It contains the necessary electronic tools for communication and file sharing, therefore, students mark it as a significant resource in the implementation of educational activities and the formation of digital competence.

To check the level of digital competency formation, teachers evaluated students' project activities by the following criteria: does the student use multimedia tools; what electronic means does it use to interact with other project participants; does it take advantage of cloud storage, how the student builds correspondence in the framework of the Chat, Forum, e-mail; Does the student use electronic library systems and databases. 
Checking the level of formation of digital competencies of students was carried out in 2017, 2018 and 2019. The results are shown in Figure 2.

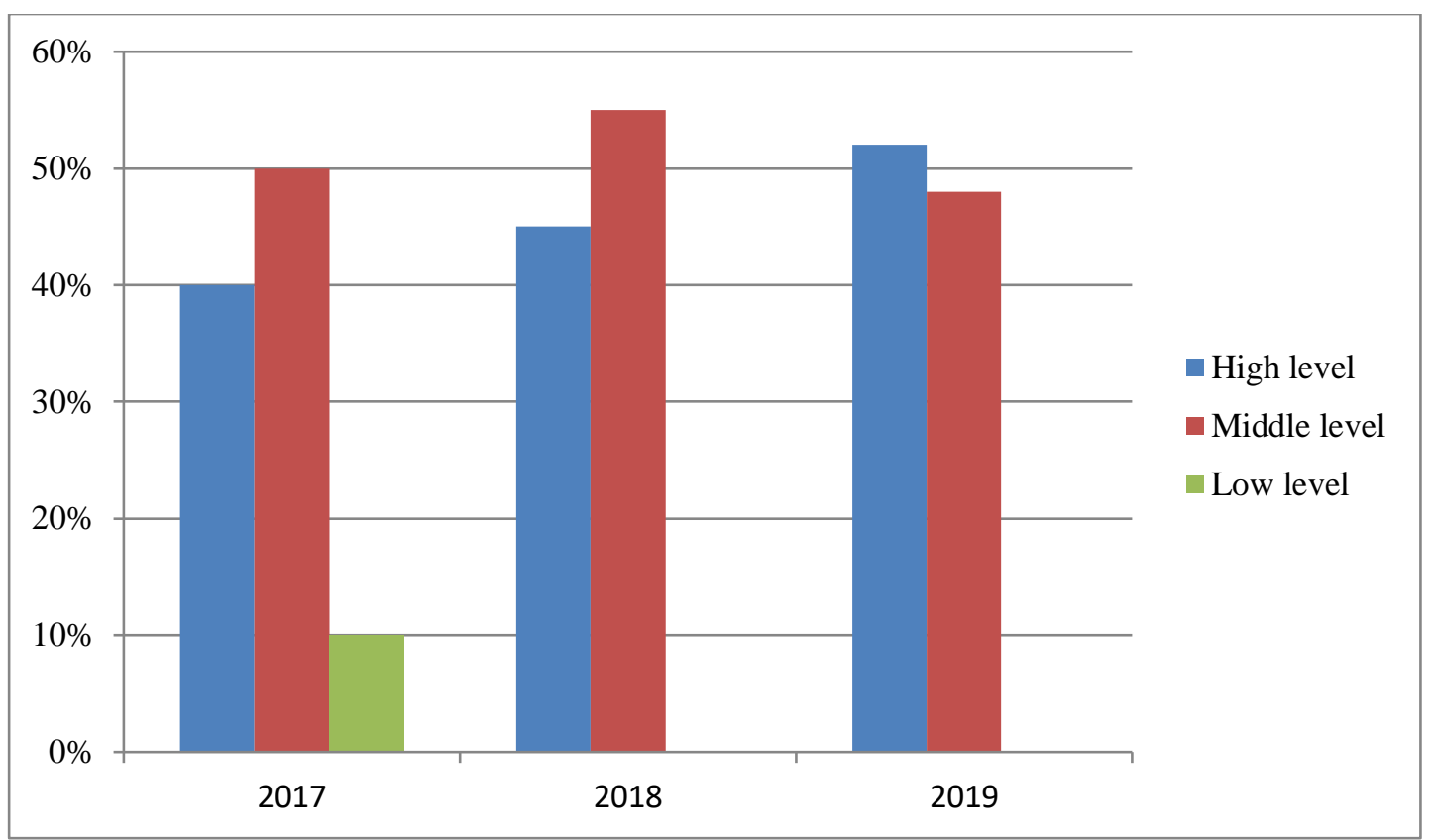

Fig. 2. Results of testing the level of students' formation of digital competencies for 2017, 2018, 2019 (as part of our research)

Statistical data processing allowed us to establish an increase in the number of students with a high level of digital competence. If in 2017 a high level was observed in $40 \%$ of students, by 2019 this percentage has increased to $52 \%$. A high-level means that students have "advanced" digital skills and are able not only to use various electronic educational tools, online applications and services, evaluate the sources and relevance of the data obtained, but also have the basics of programming and networking skills. A large percentage of students have an average level of digital competence formation, which shows the conscious use of digital technologies. formed skills of search selection, selection of relevant information sources. The student knows and uses the means of videoconferencing, webinars and streams. can conduct business correspondence by using email. All participants in the educational process are able to use social networks as a means for selfeducation and self-improvement.

\section{Conclusions}

We have carried out the analysis of the experience of the formation of institutions of higher learning digital competences of bachelors. Digital competencies are of high importance in the training of modern students. Digital skills are related to the ability to correctly apply digital technologies to solve various functional tasks. Mastering these skills guarantees the effective use of digital technologies and obtaining real practical results. These competencies involve creative actions necessary to work in online applications and digital services. This includes social networks, messengers, information portals, library and scientific services, and databases. The study participants showed a high level of digital competence formation. For their formation, the higher educational institution implements a system of mutually based actions, which includes advanced electronic tools. In the framework of the study, it was found that all students have Internet literacy to perform tasks on the Internet. They have not only basic digital skills, but are also able to effectively use the necessary computer applications, including a wide range of software, use search engines, process and manage files, quickly adapt to new digital resources, and manage media sources. 
The results of the study show that the gradual introduction of innovative electronic technologies in the educational process increases the level of formation of digital competencies of students every year. The use of electronic tools and technologies contributes to the preparation of a highly qualified bachelor in demand on the labor market, who is ready to effectively use information resources and technologies in order to develop solutions to problem situations.

Conflict of interests: The authors declare that they have no conflicts of interest.

Authors' contribution: The authors have participated in the research process, in the writing of the work and in the analysis of the documents.

\section{Bibliographic references}

Aleksieienko-Lemovska, L.V. (2019). The activity approach as a basis for preschool teachers' methodological activities. Humanitarian Balkan Research, 3, 4(6), 10-14.

Andrienko, O.A. (2019a). On the need to apply gaming training technologies. Balkan Scientific Review, 2 (4), 5-8.

Andrienko, O.A. (2019b). Modern educational technologies: technology of self-presentation. Balkan Scientific Review, 1(3), 5-7.

Andriushchenko, T. K., (2018). Personal aspects of pedagogue's innovative culture. Scientific Vector of the Balkans, 1, 13-16.

Arbeláez-Campillo, D.F., \& Rojas-Bahamon, M.J (2020). "Pandemics in globalization times". Amazonia Investiga, $9(27), \quad 3-4$. https://amazoniainvestiga.info/index.php/amazonia/article/view/1189

Bakharev, N. P. (2019). Creativity - a prerequisite for the formation of professional competences in specialists of technical direction of training. Scientific Vector of the Balkans, 3, 4 (6), $17-21$.

Chertovskikh, O.O. (2019). Prospects for the use of digital resources in education. Baltic Humanitarian Journal. 8, 4 (29), 184-187.

Chil Núñez, I., Escalona Arranz, J., Molina Bertrán, S., Dutok Sánchez, C., Arias Ramos, D., Pérez Rondón, L., Ochoa Pacheco, A., \& Picanço Souto, R. (2020). Perfeccionamiento de la estrategia curricular de medio ambiente de la carrera de ciencias farmacéuticas de la Universidad de Oriente, Cuba. Revista Científica Del Amazonas, 3(5), 6-17. https://revistadelamazonas.info/index.php/amazonas/article/view/24

Cirdan, A.P. (2019). Innovative technologies of professional training of future economists in the system of continuous education. Humanitarian Balkan Research, 2(4), 27-30.

Donetskova, O.YU. (2019). Modernization of the modern education system in Russia. Baltic Humanitarian Journal, 8, 2 (27), 37-39.

Filchenkova, I.F. (2019). Educational management of innovative activity of teachers as an object of pedagogical research. Vestnik of Minin University, 2019.7 (4), 3.

Fross, K., Winnicka-Jasłowska, D., \& Sempruch, A. (2018). «Student zone» as a new dimension of learning space. Case study in Polish conditions (Conference Paper). Advances in Intelligent Systems and Computing Volume, 77-83 
Gladkov, A.V., Vaganova, O.I., \& Prokhorova, M.P. (2019). Modern pedagogical technologies as a means of enhancing educational motivation. Baltic Humanitarian Journal, 8, 1 (26). 274-276.

Grigoriev, S. G., Shabunina, V. A., Tsarapkina, Ju. M., \& Dunaeva, N. V. (2019). Electronic library system as a means of self-development of students of digital generation $\mathrm{Z}$ (on the example of studying the course "Basics of the counselor activity") - Scientific and technical libraries. No. 7. Pp. 78-99. 29.

Halatsyn, K.A. \& Feshchuk, A.M. (2019). Diagnosing motivational-and-valuable component of the communicative culture of students in higher technical educational institutions. Balkan Scientific Review, 3, 2 (4), 17-20.

Klinkov, G.T. (2018). The specificity of manifestation of pedagogical communication as a special construct. Scientific Vector of the Balkans, 1, 51-52.

Oros, I.I. (2018) The role of international connections in the development of the adult education system. Humanitarian Balkan Research, 1, 57-59.

Petrichev, P. V., Masyuk, N. N., \& Bushueva, M. A. (2018). Method of estimation of the effectiveness of the partnership russian universities with foreign educational organizations. Azimuth of Scientific Researches: Economics and Management, 7, 3 (24), 229-232.

Pichugina, G. A., \& Zhilyakova, D. A. (2019) Structuring the organization of the process of creativity. Scientific Vector of the Balkans, 3, 3 (5), 55-58.

Pinkovetskaia, I.S, Arbeláez-Campillo, D.F., Rojas-Bahamón, M.J., \& Veas Iniesta. D. (2020). "Motivation of new entrepreneurs in modern economies" Amazonia Investiga, 9(29), 368-373. https://amazoniainvestiga.info/index.php/amazonia/article/view/1403

Pisarenko, D. A. (2019). Evaluation of extracurricular activities of university students with a competency-based approach. Scientific Vector of the Balkans, 3, 3 (5), 37-40.

Pliushch, V.M. (2018). Independent work of students as a factor of improving education quality. Balkan Scientific Review, 1, 69-71.

Ponachugin, A.V., \& Lapygin, Yu.N. (2019). Digital educational resources of the university: design, analysis and expertise. Vestnik of Minin University, 7 (2), 5.

Quarles, A. M., Conway, C. S., Harris, S., Osler, J., \& Rech, L. (2017). Integrating digital/mobile learning strategies with students in the classroom at the historical black college/university (HBCU), Mobile Learning, and Technology Integration Models in Teacher Education, 390-408.

Raven, J. (2017). Education and Sociocybernetics. Azimuth of Scientific Researches: Economics and Management, 6, 3 (20), 289-297.

Tolkanuk, Z. A. (2019). Professional self-determination of youth as a factor of training of a competent specialist. Balkan Scientific Review, 3, 2 (4), 57-59.

Tsarapkina, Ju. M., Dunaeva, N. V., \& Kireicheva, A. M. (2019b). Application of BYOD technology in education on the example of Lecture Racing mobile application. Informatics and Education, 9 (308), 56-64. 
Tsarapkina, Ju.M., Petrova, M.M., Mironov, A.G., Morozova, I.M., \& Shustova, O.B. (2019a). Robotics as a basis for Informatization of education in children's health camp. Amazonia Investiga, 8 (20). $115-123$. https://www.amazoniainvestiga.info/index.php/amazonia/article/view/70

Vaganova, O.I., Ilyashenko, L.I., Smirnova, Zh.V., Bystrova, N.V., \& Kaznacheeva, S.N. (2019a). Students' creative abilities development in higher educational institution. Amazonia Investiga 8 (22), 701-710. https://www.amazoniainvestiga.info/index.php/amazonia/article/view/822

Vaganova, O.I., Livshits, Yu.A., Aleshugina, E.A., Smirnova, Zh.V., \& Kutepova, L.I. (2019c). Experience in developing electronic glossary in a higher education institution. Amazonia Investiga, 8 247-253. https://www.amazoniainvestiga.info/index.php/amazonia/article/view/421

Vaganova, O.I., Rudenko, I.V., Markova, S.M., Smirnova, Zh.V., \& Kutepov, M.M. (2019b). The use of educational video materials in educational process of a higher educational $\begin{array}{lllll}\text { institution. } & \text { Amazonia } & \text { Investiga, } & 8 & \text { (22), }\end{array}$ https://www.amazoniainvestiga.info/index.php/amazonia/article/view/308

Vaskovskaya, G.A. (2018). Features of implementation of pedagogical technologies of profile training. Balkan Scientific Review, 1, 76-79. 